\title{
Efectul moderator al angajamentului organizațional asupra relației dintre sursele de presiune şi consecințele stresului, în cazul unei achiziții internaționale
}

\author{
Andrea Budean ${ }^{1}$, Horia D. Pitariu \\ Universitatea Babeş-Bolyai, Cluj-Napoca
}

\begin{abstract}
Mergers and acquisitions are corporate events with the potential of creating a high level of stress, with psychological, behavioural and physical consequences, raising problems to both: the functionality of the individuals and of their organizations. In the context of growth of foreign direct investments in Romania and the lack of researches conducted on this type of organizational combinations, this study aims to identify the main stressors associated with the acquisition of a Romanian company by a foreign investor and the moderating effect of organizational commitment of the stress - outcomes relationship. The research was based on the stress model developed by Cartwright \& Cooper (2002). The results revealed a moderate level of stress, moderate personal health and a low level of organizational commitment. We did not find support for the moderator role of organizational commitment on the stress-outcome relationship. Only the direct effect of stress on physical health and psychological wellbeing were supported. The hierarchical regression revealed that the perceived commitment of the organization toward its members moderates the stress health relationship. We regard these results as optimistic, suggesting possibilities of managing the post-acquisition integration process in a manner that diminishes the negative consequences generally associated with these changes.
\end{abstract}

Key words: occupational stress, organizational commitment, moderation, mergers and acquisitions.

\section{Résumé}

Les fusions-acquisitions sont des événements corporatistes qui ont le pouvoir de créér un haut niveau de stress, avec des conséquences au niveau psychologique, comportemental et physique, en soulevant des problèmes sérieux en ce qui concerne le fonctionnement des individus, ainsi que celui des entrerprises où ils travaillent. Dans le contexte de l'intensification des investissements étrangères directs en Roumanie, sous la forme des acquisitions, et de l'absence des recherches psychologiques dans le domain de ce type de transformations organisationnelles, le but de cet étude est d'identifier les principales sources de stress rencontrées dans le contexte d'une entreprise roumaine, acquisitionnée par un investisseur étranger, et l'effet de modération de l'engagement organisationnel sur la relation entre les facteurs du stress et la santé. La recherche a été fondée sur le modèle du stress dévéloppé par Cartwright \& Cooper (2002). Les résultats obtenus ont souligné un niveau modéré du stress ressenti, ainsi que de la santé physique et psychologique, en échange ils ont mis en évidence un niveau réduit de l'engagement envers l'organisation, ainsi que de l'engagement perçu de l'organisation envers ses employés. On n'a pas obtenu un support pour le rôle de modérateur de l'engagement envers l'organisation, les résultats obtenus soutennant seulement un effet direct de ce support sur la santé physique et psychologique. Cependant l'annalyse de régression hiérarchique a mis en évidence l'effet modérateur de l'engagement perçu de l'organisation vers l'employé, dans la relation entre les sources du stress et les conséquences de celui-ci sur la la santé physique et psychologique. On considère que les résultats obtenus sont optimistes, suggérant des possibilités de management du procés d'intégration d'une manière qui puisse réduire les effets négatives, asociés en général à ces changements.

Mots clés: stress occupationnel, engagement organisationnel, modération, fusions-acquisitions

Adresa de corespondență: andrea.budean@gmail.com 


\section{Introducere}

Fuziunile şi achizițiile continuă să se numere printre cele mai populare strategii de dezvoltare corporațională. În 2004, la nivel global s-au încheiat 30.000 de achiziții, echivalentul unei tranzacții la fiecare 18 minute (Cartwright \& Schoenberg, 2006). În România, anul 2006 a înregistrat un număr de 134 de achiziții finalizate în sectorul privat, reprezentând o creştere de peste 15\% în comparație cu 2005, în timp ce valoarea investițiilor străine directe a înregistrat în acelaşi an o creştere cu $75 \%$ față de anul precedent (PriceWaterhouse Cooper, Raport de țară, 2006).

În ciuda popularității de care se bucură, rezultatele referitoare la performanțele achizițiilor sunt în cel mai bun caz mixte. Estimările referitoare la rata eşecului înregistrat de fuziuni şi achiziții variază între procente pesimiste, ca şi $77 \%$ raportate în anumite studii americane (Marks, 1988) şi rezultate ceva mai favorabile $(50 \%)$ menționate în câteva surse din Marea Britanie (Cartwright \& Cooper, 1995). Studii similare realizate pe cazurile unor parteneriate strategice arată că în ciuda resurselor financiare de care beneficiază, aceste tipuri de colaborare sunt foarte instabile şi aproximativ o pătrime dintre acestea încetează să existe în primii trei ani de la momentul realizării alianței (Kogut, 1988, în Cartwright \& Cooper, 1995).

Tot mai frecvent, absența succesului achizițiilor este atribuită factorilor umani (Applebaum, Lefrancois, Tonna \& Shapiro, 2007). Efectele achiziției asupra angajaților se concretizează adesea într-un nivel ridicat de stres şi anxietate, care persistă în timp (Schweiger \& DeNisi, 1991; Applebaum et al., 2007) şi influențează negativ nivelul productivității şi calitatea muncii realizate. Cartwright \& Cooper (1994) enumeră o serie de consecințe negative, care apar în urma stresului provocat de achiziții: rate ridicate ale demisiilor (Walsh, 1988), absenteism (Davey et al., 1988), comportament contraproductiv (Sinetar, 1981) şi sabotajul organizației (Altendorf, 1986). Panchal \& Cartwright (2001) afirmă că achizițiile ar putea fi comparate cu evenimente de viață ca şi pierderea unui membru al familiei sau falimentul. Consecințe psihologice ale încetării existenței unei organizații, în urma achiziție sale, sunt extrem de negative pentru membrii acestora (Cartwright \& Cooper, 1990).

În ciuda creşterii numărului fuziunilor şi achizițiilor în România şi a impactului semnificativ al acestora asupra angajaților, literatura psihologică în acest domeniu a fost surprinzător de tăcută. Studiul de față îşi propune să identifice principalele surse de stres cu care se confruntă angajații unei firme româneşti, care a trecut prin experiența unei achiziții internaționale şi testeze potențialul efect moderator al angajamentului asupra relației dintre factorii de stres şi consecințele acestora asupra sănătății fizice şi psihice a angajaților. Ipoteza efectului moderator al angajamentului nu este nouă. Caracterul de noutate al acestui studiu constă în testarea efectului moderator al angajamentului perceput al organizației față de angajat, pe lângă abordările clasice, în care $s$-a luat în considerare doar efectul angajaților față de organizație (Leong, Furnham \& Cooper, 1996, Irving \& Coleman, 2003).

\section{Stresul ocupațional în fuziuni şi achiziții}

Cercetări recente au subliniat potențialul stresant şi costisitor al fuziunilor şi achizițiilor (Cartwright \& Cooper, 1996; Cartwright \& Hudson, 2000). Ivancevich, Schweiger \& Power (1987) consideră că fuziunile şi achizițiile confruntă angajații companiilor implicate cu cel puțin trei realități îngrijorătoare: (1) realitatea unui eveniment major, asupra căruia ei nu au nici un fel de control; (2) incertitudinea cu privire la viitorul profesional şi (3) schimbări la nivelul posturilor de muncă, relațiilor profesionale şi familiale. $O$ parte dintre factorii de stres asociați cu fuziunile şi achizițiile sunt temporari (ex. vulnerabilitatea la pierderea locului de muncă), în timp ce alții pot persista pentru perioade îndelungate de timp (ex. ambiguitatea şi schimbarea culturală, care depind de viteza cu care se realizează integrarea). În funcție de felul în care sunt evaluate şi interpretate schimbările implicate de o fuziune sau achiziție, evenimentul organizațional este considerat de către angajați ca şi o amenințare, o oportunitate sau irelevant (Ivancevich et al., 1987). În ciuda acestor trei posibilități teoretice, există un acord puternic la nivelul cercetărilor cu privire la efectul stresant şi destabilizator al fuziunilor asupra organizațiilor şi membrilor acestora. 
În literatura de specialitate au fost propuse modele ale stresului în fuziuni şi achiziții (Bruckman \& Peters, 1987; Schweiger \& Ivancevich, 1985) care aproximează într-o mare măsură modelele generale ale stresului ocupațional. Cartwright \& Hudson (2000) descriu patru categorii majore de stresori ocupaționali, identificați în literatura de specialitate ca specifici fuziunilor şi achizițiilor: stresul asociat cu supraviețuirea în organizație, stresul asociat cu pierderea identității şi incertitudinea, stresul asociat cu schimbări ale condițiilor şi relațiilor de muncă şi stresul de aculturalizare. Fuziunile şi achizițiile sunt considerate într-un mod excepțional evenimente organizaționale stresante, datorită faptului că acționează simultan asupra tuturor acestor categorii de stresori, într-un mod mult mai acut decât orice altă formă de restructurare organizațională (Shaw et al., 1993, în Cartwright \& Hudson, 2000).

\section{Consecințe ale stresului ocupațional}

Importanța stresului ocupațional constă tocmai în gravitatea consecințelor sale asupra individului şi a organizației. La nivel individual, aceste consecințe vizează starea de sănătate fiziologică şi psihologică, dar şi spectrul atitudinal şi comportamental. Un studiu calitativ (Schweiger, Ivancevich \& Power, 1987) arată că angajații unei companii care au trecut printr-un proces de fuziune au raportat ulcer, migrene şi tulburări alimentare, ca rezultat al acestei schimbări. Citându-i pe Siu, Cooper \& Donald (1997), Cartwright \& Hudson (2000) arată că nivelul ridicat de stres experimentat de un lot de muncitori chinezi din cadrul unei companii de televiziune care a trecut printr-o fuziune a fost asociat cu un nivel redus al sănătății mentale. Rezultate similare au fost obținute în cazul unei fuziuni din sectorul financiar (Cartwright \& Cooper, 1993), unde un număr neobişnuit de mare de manageri de mijloc au raportat un nivel redus al sănătății mentale. În câteva cazuri extreme, indivizii au raportat tendințe de suicid la aflarea veştii achiziționării companiei (Buono \& Bowditch, 2003). Consecințele atitudinale ale stresului includ, fără a fi limitate la, insatisfacție profesională şi angajament redus față de organizație.

La nivel organizațional, se conturează două consecințe majore ale stresului ocupațional: neimplicarea individului şi performanța profesională redusă (Cartwright \& Cooper, 1993a, b). Întârzierile, absenteismul, fluctuațiile de personal şi retragerea psihologică sunt câteva tipuri de neimplicare, consecințe ale angajament redus. Acestea apar în momentul în care angajatul percepe locul de muncă ca fiind neplăcut şi încearcă să îl evite. Eşecul în managementul stresului ocupational poate crea costuri ridicate pentru organizații în termeni de productivitate redusă, performanță redusă, costuri medicale ridicate şi pierderea personalului cu experiență profesională.

Cel mai adesea, studiile din domeniul fuziunilor şi achizițiilor privesc stresul ocupațional ca un fenomen indezirabil, provocat de resurse inadecvate pentru a face față solicitărilor asociate cu o anumită situație de schimbare organizațională radicală şi care au o serie de consecințe negative asupra sănătății fizice şi psihologice a angajaților (Cooper \& Payne, 1988). Totuşi, în ciuda unei relații bine stabilite între stres şi sănătate, există indivizi care reuşesc să îşi păstreze starea de bine chiar şi în ciuda unor circumstanțe extrem de stresante (Terry et al., 1996). Aceste date de cercetare, au provocat un număr din ce în ce mai mare de cercetători să examineze potențialii mediatori şi moderatori ai relației stresori - consecințe ale stresului în domeniul ocupațional (Cooper \& Bramwell, 1992; Leong, Furnham \& Cooper, 1996).

\section{Angajamentul organizațional}

Un potențial moderator al relației stresori - consecințe este angajamentul organizațional (Mathieu \& Zajac, 1990; Somers, 1995). Angajamentul organizațional a fost definit şi măsurat în diferite moduri. Tema centrală care se regăseşte însă în majoritatea definițiilor propuse este aceea că angajamentul organizațional reprezintă 0 legătură între individ şi organizație. Conceptual, angajamentul poate fi caracterizat prin cel puțin trei factori: (a) o acceptare puternică a obiectivelor şi valorilor organizaționale; (b) dorința de a depune efort considerabil, spre binele organizației şi (c) o dorință puternică de a menține membralitatea în organizație (Irving \& Coleman, 2003).

Interesul susținut al cercetătorilor față de angajamentul organizațional constă în relațiile acestuia cu o serie de rezultate organizaționale importante. Un nivel ridicat al angajamentului este asociat cu o rată redusă a fluctuației de personal, a absenteismului şi un nivel ridicat al performanțelor profesionale. Mathieu \& Zajac (1990) arată că angajații care 
raportează un nivel ridicat al angajamentului nu doar că nu se implică în comportamente contraproductive, ci se implică în comportamente care depăşesc atribuțiile formale ale rolului lor, contribuind astfel la menținerea nivelului competitiv al organizatiei. Indicând beneficiile acestui construct pentru individ, Kobasa (1982) şi Begley \& Czajka (1993) afirmă că angajamentul protejează angajații de consecințele negative ale stresului, conferind direcție şi semnificație muncii acestora.

Rezultatele studiilor care abordează impactul schimbărilor organizaționale implicate în fuziuni şi achiziții asupra atitudinilor organizaționale susțin aproape în unanimitate efectul negativ al acestora asupra satisfacției cu locul de muncă şi organizația (Buono \& Bowditch, 2003; Cartwright \& Cooper, 1993) şi asupra angajamentului față de organizație (Buono \& Bowditch, 2003; Marks \& Mirvis, 1992; Davy et al., 1988). Newman \& Krzystofiak (1993) arată că percepția caracteristicilor postului, satisfacția profesională şi siguranța postului înregistrează un declin, chiar şi în contextul achizițiilor prietenoase. Schweiger \& DeNisi (1991) arată pe baza unui studiu longitudinal că atitudinile negative dezvoltate față de o situație de achiziție sau fuziune se păstrează pentru perioade îndelungate de timp. Fairfield-Sonn, Ogilvie \& DelVecchio (2002) demonstrează experimental că tipul achiziției (ostil/prietenos) determină consecințe atitudinale diferite, iar suportul perceput din partea organizației în contextul implementării acestor schimbări, are un impact puternic asupra angajamentului lor față de organizație. Considerăm că în acest context, devine şi mai relevantă investigarea rolului pe care aceste atitudini îl au asupra consecințelor stresului.

\section{Efectul moderator al angajamentului organizațional asupra consecințelor stresului}

Modelul cognitiv-afectiv al stresului (Lazarus \& Folkman, 1984, în Folkman, Lazarus, Dunkel-Schetter, DeLongis \& Gruen, 1986; Lazarus, DeLongis, Folkman \& Gruen, 1985) susține că maniera în care indivizii evaluează şi interpretează stresorii care acționează asupra lor determină consecințele acestora (nivelul subiectiv de stres resimțit). $O$ implicație directă a acestei afirmații este aceea că indivizii vor reacționa diferit la aceeaşi situație stresantă, în funcție de interpretarea pe care 0 ataşează acesteia. Cercetările realizate în contextul unor schimbări intraorganizaționale majore (Ashford, 1988) arată că acestea sunt universal stresante şi foarte puțin moderate de caracteristicile de personalitate ale angajaților (Cartwright \& Cooper, 1994). Nici variabilele demografice nu s-au dovedit a modera impactul achizițiilor asupra atitudinilor față de organizație (satisfacția profesională şi angajamentul față de organizație), în urma unei achiziții (Newman \& Krzystofiak, 1993). Prin urmare, atenția cercetătorilor s-a îndreptat asupra rolului atitudinilor organizaționale ca potențiali moderatori ai relației dintre factorii de stres şi consecințe (Begley \& Czajka, 1993; Leong, Furnham \& Cooper, 1996; Reilly, 1994). În mod specific, a crescut interesul față de rolul angajamentului față de organizație în relația dintre stresori şi consecințele acestora, în specia în situații de confuzie şi turbulență organizațională. Cea mai mare parte a cercetărilor realizate asupra rolului angajamentului organizațional în relația stresori - consecințe a fost alimentată de două ipoteze concurente (Irving \& Coleman, 2003): (1) Prima dintre ele (Mathieu \& Zajac, 1990) este aceea că angajații care manifestă un angajament puternic față de organizație vor simți mult mai puternic efectul stresului, decât angajații care sunt mai puțin loiali organizației. (2) Ce-a de-a doua perspectivă susține exact opusul, şi anume că angajamentul protejează indivizii de efectele negative ale stresului, datorită faptului că îi ajută să găsească o directie şi semnificatie pentru munca lor (Kobasa, 1982). Citându-I pe Antonovsky (1979). Leong et al. (1996) susțin că angajamentul este o resursă crucială, care ajută angajații să reziste în fața tensiunilor din mediul organizațional. Această perspectivă susține că stresul duce la apariția consecințelor negative în contextul unui nivel redus al angajamentului.

Rezultatele unui studiu realizat de Panchal \& Cartwright (2001) relevă existența unor diferențe semnificative între angajații companiei achiziționate şi ai celei achizitoare, atât la nivelul surselor, cât şi la nivelul consecințelor stresului. În mod surprinzător, aceste diferențe însă nu au fost în direcția aşteptată de autori. În explicarea rezultatelor, Panchal \& Cartwright (2001) au făcut apel la nivelul redus al angajamentului organizațional în cazul companiei achizitoare şi la teoria identității sociale. Achiziția a constituit o oportunitate de dezvoltare a identității sociale pentru angajații companiei cumpărate, în timp 
ce pentru angajații companiei cumpărătoare, această acțiune a însemnat o reducere a acesteia. Semnificația atribuită de angajați acestui eveniment a avut un impact semnificativ asupra angajamentului față de organizație şi asupra surselor şi consecințelor stresului. Rezultate similare cu privire la atitudinile față de organizație fost obținute şi de Terry et al. (1996). În afara acestor două studii, care surprind indirect posibilitatea rolului moderator al angajamentului în relația stresoriconsecinte, această relație nu a fost testată sistematic în contextul fuziunilor şi achizițiilor. Nici impactul angajamentului perceput al organizației față de angajat nu a făcut obiectul unor cercetări empirice, cu toate că o serie de studii au surprins impactul suportului perceput din partea organizației şi a justiției procedurale asupra reacțiilor angajaților la achiziției şi a succesului integrării (Davy et al., 1988; Elsass \& Veiga, 1994, Larsson \& Lubatkin, 2001). Clarificarea acestor relații este esențială, deoarece ar putea sugera modalități eficiente de intervenție în scopul reducerii consecințelor negative şi costisitoare ale stresului în contextul fuziunilor şi achizițiilor. Ne aşteptăm ca indivizii care percep un nivel ridicat al angajamentului organizației față de membrii să fie mai puțin afectați de stres, comparativ cu cei care percep un angajamentul redus al organizației față de ei.

\section{Obiectivele cercetării}

Cercetarea de față este fundamentată pe modelul stresului dezvoltat de Cartwright \& Cooper (2002) prezentat în Figura 1. Sursele de presiune luate în considerare de model sunt: relațiile profesionale; echilibrul dintre viața personală şi cea profesională, supraîncărcarea muncii, siguranța postului de muncă; controlul; resursele şi comunicarea, plățile şi beneficiile. Astfel, un prim obiectiv al acestui studiu a fost acela de a identifica principalii factori evaluați ca stresanți de angajații români, care au trecut prin experiența unei achiziții internaționale.

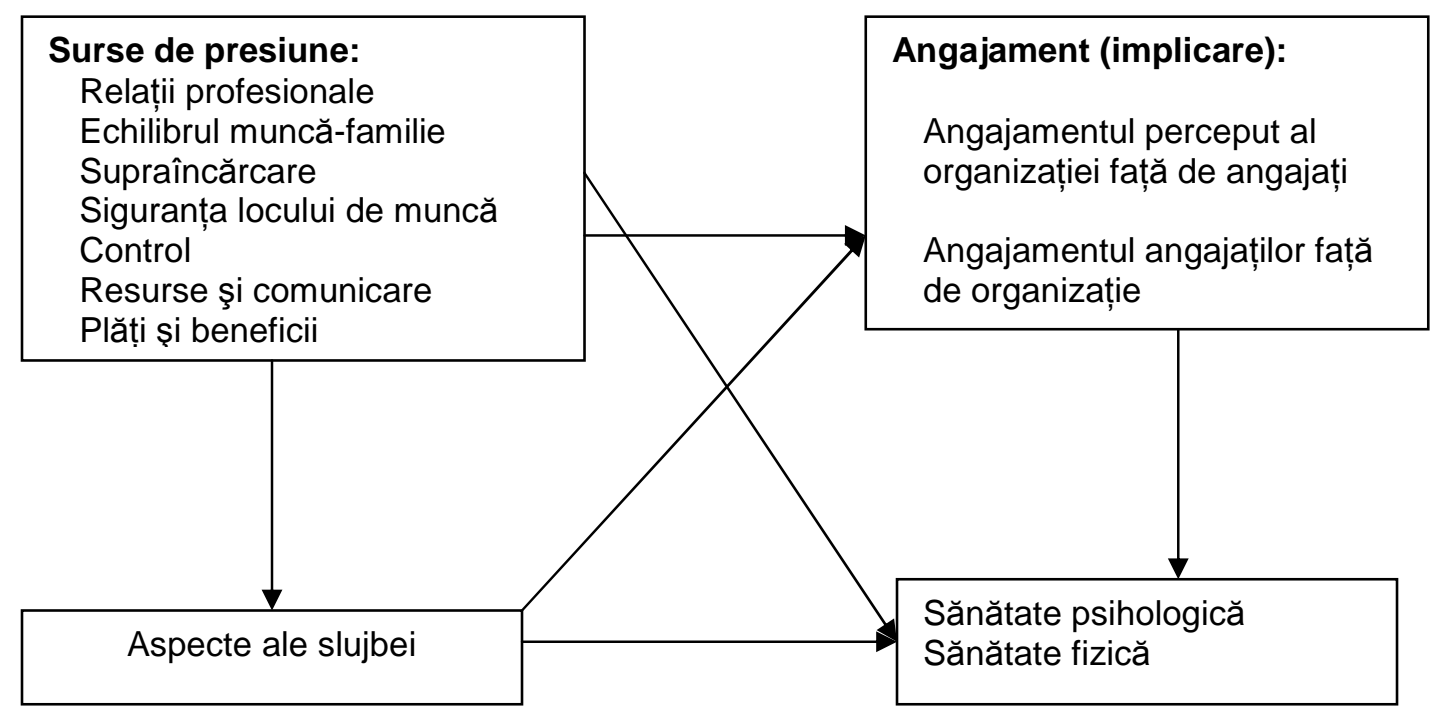

Figura 1. Cadrul teoretic al stresului conform ASSET (sursa: Pitariu, Tureanu \& Peleaşă, 2008)

Modelul susține că principalele surse de presiune existente în organizații pot duce la înrăutățirea nivelului sănătății fizice şi psihologice a angajaților, dar această relație este moderată de diferențe demografice şi diferențe la nivelul atitudinilor față de organizație. Unul dintre aspectele unice ale modelului constă în definirea percepției gradului de implicare/angajare pe ambele direcții ale relației organizație - angajat şi recunoaşterea faptului că aceasta poate fi atât un efect, cât şi o cauză a stresului (Pitariu, Tureanu \& Peleaşă, 2008). Această caracteristică a modelului, dar şi datele de cercetare, sumarizate mai sus, au dus la formularea celui de-al doilea obiectiv al studiului şi anume: examinarea potențialul efect de moderare al angajamentului organizațional şi al angajamentului perceput al organizației față de membrii săi, asupra relației dintre factorii de stres şi consecințele stresului, într-o organizație care a trecut printr-un proces semnificativ de schimbare.

Pe baza celui de-al doilea obiectiv, am formulat următoarele ipoteze: 
H1a: Angajamentul angajaților față de organizație va modera relația dintre stresorii organizaționali şi sănătatea fizică.

H1b: Angajamentul angajaților față de organizație va modera relația dintre stresorii organizaționali şi sănătatea psihologică.

H2a: Angajamentul perceput al organizației față de membrii săi va modera relația dintre stresorii organizaționali şi sănătatea fizică.

H2a: Angajamentul perceput al organizației față de membrii săi va modera relația dintre stresorii organizaționali şi sănătatea psihologică.

\section{Metodologia cercetării}

\section{Participanți}

Studiul a fost realizat pe un eşantion de 142 de participanți, dintre care 30 de gen masculin $(21,1 \%), 111$ de gen feminin $(78,2 \%)$, iar o persoană nu şi-a declarat sexul. Vârsta participanților variază între 21 şi 60 de ani, $32,4 \%$ având între $21-30$ de ani, 35,9\% între 31 şi $40,23,2 \%$ între 41 şi 50 de ani şi $8,5 \%$ între 51 şi 60 . Nivelul de educație este ridicat, $50,7 \%$ sunt absolvenți de facultate, $37,8 \%$ au studii postuniversitare, $10 \%$ sunt absolvenți de liceu şi $1,4 \%$ absolvenți de şcoală generală. Referitor la situația familială a participanților, $62,7 \%$ sunt căsătoriți, $17,6 \%$ conviețuiesc cu un partener, $13,4 \%$ sunt divorțați, $2,1 \%$ văduvi şi o persoană nu şi-a declarat starea civilă. Dintre cei care sunt căsătoriți sau conviețuiesc cu un partener, $78,9 \%$ afirmă că partenerul lucrează şi $6,3 \%$ că nu lucrează. 21 de participanți nu au făcut nici un comentariu referitor la statutul ocupațional al partenerului de viață. Angajații participanți la cercetare provin din toate departamentele companiei, după următoarea structură: 4 persoane lucrează în departamentul de producție, 10 la resurse umane, 20 la financiar, 11 în IT, 1 persoană este responsabilă de relațiile cu clienți, 19 în vânzări şi marketing, 1 protecția muncii, 2 logistică, 5 achiziție, 17 cercetare şi dezvoltare şi 17 în alte departamente, care nu s-au regăsit pe structura furnizată de chestionar. Dintre aceştia, 141 lucrează cu normă întreagă şi 1 persoană cu normă redusă. Ca şi nivel ocupațional, $12,7 \%$ sunt manageri şi directori de departamente, $26,8 \%$ au ocupații profesionale, $10,4 \%$ au ocupații tehnice, $7,7 \%$ au ocupații administrative şi de secretariat, $23,2 \%$ au ocupații calificate, $11,3 \%$ lucrează pe posturi de vânzări şi relații cu clienții, 1,4\% au ocupații tehnologice şi 1,4\% ocupații de bază.

\section{Instrumente}

Pentru investigarea surselor de presiune din cadrul organizației şi ale reacțiilor fizice şi psihologice ale angajaților la stres s-a utilizat tot chestionarul ASSET (A Shortened Stress Evaluation Tool) dezvoltat de Cooper \& Cartwright (2002). ASSET este alcătuit din patru secțiuni, care investighează percepția surselor de presiune la locul de muncă (8 scale) şi efectele stresului la locul de muncă: atitudinea față de organizație (2 scale), sănătatea fizică şi sănătatea psihologică. Instrumentul conține şi un supliment care strânge exclusiv date demografice. Acest instrument a fost ales pe baza calităților sale psihometrice $\square \mathbf{i}$ a utilizabilității ridicate, care a dus în general la rate ridicate de răspuns (Faragher, Cooper \& Cartwright, 2004).

\section{Procedura}

Chestionarele au fost completate de către participanți în varianta creion hârtie, în timpul programului de lucru, după ce le-a fost explicat scopul, modalitatea corectă de completare şi doar dacă respondenții şi-au exprimat acordul prealabil.

\section{Rezultate}

Mediile, abaterile standard, valoarea coeficientului de consistență internă Alpha Cronbach şi corelațiile dintre variabilele investigate sunt prezentate în Tabelul 1. În plus, scorul mediu obținut pentru fiecare scală din chestionar este încadrat într-una din scalele sten, conform etalonului construit pe populația românească din sectorul privat (Pitariu, Tureanu \& Peleaşă, 2008).

Inspecția valorilor obținute pentru coeficientul de consistență internă Alpha Cronbach reflectă o bună fidelitate a scalelor utilizate. $\mathrm{Cu}$ excepția scalelor: Postul de muncă $(\alpha=.64)$, Resurse şi comunicare $(\alpha=.55)$ şi Salarizare şi beneficii (conține un singur item), pentru toate celelalte $\mathrm{s}$-au obținut coeficienți cu valori care depăşesc pragul general acceptat de .70 .

Secțiunea Percepții asupra muncii conține scalele care măsoară sursele de presiune din cadrul organizației. $O$ analiză generală a rezultatelor obținute la cele 8 scale indică un nivel mediu al stresului, scorurile obținute corespund claselor sten 5 şi 6 din 
Tabelul 1. Indicatorii descriptivi şi intercorelațiile dintre variabilele incluse în studiu

\begin{tabular}{|c|c|c|c|c|c|c|c|c|c|c|c|c|c|c|c|}
\hline & 1 & 2 & 3 & 4 & 5 & 6 & 7 & 8 & 9 & 10 & 11 & 12 & 13 & 14 & 15 \\
\hline 1 Sex & - & & & & & & & & & & & & & & \\
\hline 2 Vârsta & -.06 & - & & & & & & & & & & & & & \\
\hline $\begin{array}{l}3 \text { Intentia de a } \\
\text { schimba locul de } \\
\text { munca in ultimele } \\
3 \text { luni }\end{array}$ & .12 & -.00 & - & & & & & & & & & & & & \\
\hline $\begin{array}{l}4 \text { Relații } \\
\text { profesionale }\end{array}$ & -.03 & -.03 & $.27^{\star *}$ & $(.78)$ & & & & & & & & & & & \\
\hline $\begin{array}{l}5 \text { Echilibrul viata } \\
\text { personala-viata } \\
\text { profesionala }\end{array}$ & -.07 & .00 & $.23^{\star *}$ & $.38^{\star *}$ & $(.72)$ & & & & & & & & & & \\
\hline $\begin{array}{l}6 \text { Supraîncărcarea } \\
\text { muncii }\end{array}$ & .03 & .06 & $.29^{* *}$ & $.57^{* *}$ & $.62^{\star *}$ & $(.82)$ & & & & & & & & & \\
\hline $\begin{array}{l}7 \text { Siguranța } \\
\text { postului de munca }\end{array}$ & $-.23^{* *}$ & -.04 & $.16^{*}$ & $.49^{* *}$ & $.40^{\star *}$ & $.38^{\star *}$ & $(.80)$ & & & & & & & & \\
\hline 8 Control & -.01 & .10 & $.32^{\star *}$ & $.56^{\star \star}$ & $.36^{\star *}$ & $.46^{\star *}$ & $.57^{* *}$ & $(.78)$ & & & & & & & \\
\hline $\begin{array}{l}9 \text { Resurse si } \\
\text { comunicare }\end{array}$ & -.02 & .05 & $.20^{*}$ & $.60^{* *}$ & $.37^{\star *}$ & $.56^{\star *}$ & $.39^{\star *}$ & $.65^{\star \star}$ & $(.64)$ & & & & & & \\
\hline $\begin{array}{l}10 \text { Postul de } \\
\text { munca }\end{array}$ & -.14 & .13 & $.20^{*}$ & $.62^{\star *}$ & $.44^{\star *}$ & $.51^{\star \star}$ & $.53^{\star *}$ & $.53^{\star \star}$ & $.54^{\star \star}$ & $(.55)$ & & & & & \\
\hline $\begin{array}{l}11 \text { Salarizare si } \\
\text { beneficii }\end{array}$ & -.05 & .10 & .07 & $.22^{* *}$ & $.26^{\star *}$ & $.35^{\star \star}$ & .16 & $.24^{\star \star}$ & $.33^{\star *}$ & $.26^{\star *}$ & - & & & & \\
\hline $\begin{array}{l}12 \text { Angajament } \\
\text { perceput al } \\
\text { organizației fata } \\
\text { de angajat }\end{array}$ & -.10 & .06 & $-.54^{* *}$ & $-.33^{* *}$ & $-.28^{\star *}$ & $-.25^{\star \star}$ & $-.23^{* *}$ & $-.30^{* *}$ & $-.29 * *$ & $-.24^{\star *}$ & $-.17^{\star}$ & $(.84)$ & & & \\
\hline $\begin{array}{l}13 \text { Angajament } \\
\text { fata de organizație }\end{array}$ & -.06 & $.21^{*}$ & $-.34^{* *}$ & $-.28^{* *}$ & $-.31 * *$ & -.13 & $-.23^{\star *}$ & $-.18^{*}$ & -.11 & $-.22^{* *}$ & -.09 & $.74^{\star \star}$ & $(.77)$ & & \\
\hline 14 Sănătate fizica & $.34^{\star \star}$ & -.15 & $.32^{\star *}$ & .14 & .16 & $.20^{*}$ & .15 & $.19^{*}$ & .15 & .09 & .10 & $-.21^{*}$ & $-.17^{*}$ & $(.70)$ & \\
\hline $\begin{array}{l}15 \text { Sănătate } \\
\text { psihologica }\end{array}$ & $.24^{\star *}$ & -.03 & $.35^{\star *}$ & $.30^{\star *}$ & $.29^{\star \star}$ & $.44^{* *}$ & $.25^{\star *}$ & $.30^{* *}$ & $.30^{* *}$ & $.22^{\star *}$ & .13 & $-.36^{* *}$ & $-.26^{\star *}$ & $.54^{\star *}$ & $(.87)$ \\
\hline Media & & & & 21.75 & 11.4 & 12.73 & 11.05 & 13.04 & 11.88 & 22.53 & 4.15 & 17.88 & 15.32 & 12.85 & 21.09 \\
\hline $\begin{array}{l}\text { Abaterea } \\
\text { standard }\end{array}$ & & & & 7.13 & 4.19 & 4.45 & 3.10 & 4.36 & 3.63 & 5.09 & 1.50 & 4.98 & 3.94 & 3.45 & 6.09 \\
\hline Sten & & & & 6 & 5 & 6 & 6 & 6 & 6 & 5 & & 3 & 4 & 6 & 6 \\
\hline
\end{tabular}

** Corelațiile sunt semnificative la pragul de 0.01, * Corelațiile sunt semnificative la pragul 0.05, Valorile coeficientului Alpha Cronbach sunt prezentate pe diagonală, între paranteze.

Media obținută la scala Angajamentul perceput al organizației față de angajat $(\mathrm{m}=17.88$, a.s. $=4.98)$ corespunde nivelului sten 3 , ceea ce indică un nivel redus al intensității cu care angajații percep că organizația este preocupată de ei. Media scalei Angajamentul membrilor față de organizație $(m=15.23$, a.s. $=3.94$ ) corespunde nivelului 4 sten, indicând o implicare relativ redusă în muncă şi un nivel redus al dedicării şi loialității față de organizație. Valorile mediilor obținute pentru cele două scale incluse în secțiunea Sănătate personală se situează la nivelul sten 6 , indicând un nivel mediu al sănătății angajaților, atât la nivel fizic $(m=12.58$, a.s. $=3.45)$, cât şi la nivel psihologic $(m=21.09$, a.s. $=6.09)$. Datorită formulării negative a itemilor, autorii chestionarului sugerează interpretarea unui nivel mediu al sănătății ca un indicator al unei sănătăți precare (Pitariu, Tureanu \& Peleaşă, 2008).

Studiul coeficienților de corelație obținuți sugerează o asociere mai slabă între sursele de presiune din organizație şi 
sănătatea fizică, şi o asociere mai puternică şi constantă stresori şi sănătatea psihologică. Dintre factorii de stres măsurați, doar supraîncărcarea muncii $(r=.200, \quad p<.05)$ şi nivelul perceput al controlului $(r=.198, p<.05)$ corelează semnificativ cu sănătatea fizică. Rezultatele sunt mult mai convingătoare în cazul relației dintre sursele de presiune şi sănătatea psihologică a individului. Astfel dintre cele opt relații testate, şapte ating pragul semnificației statistice $(p<.001)$. Singura relație în cazul căreia valoarea coeficientului de corelație nu a fost semnificativă statistic a fost cea dintre stresul determinat de un sistem de salarizare necorespunzător şi sănătatea psihologică. Totuşi, şi în acest caz relația păstrează direcția specificată în literatura de specialitate. Conform valorilor coeficienților de corelație, cea mai puternică asociere între factorii de stres şi sănătatea psihologică apare în cazul supraîncărcării muncii $(r=.443$, $\mathrm{p}<.001)$, această valoare fiind urmată de relațiile profesionale şi resursele şi comunicarea, în ambele cazuri valoarea coeficientului de corelație fiind de $r=.308$ $(p<.001)$.

Angajamentul față de organizație corelează semnificativ cu relațiile profesionale $(r=-.28, \quad p<.001), \quad$ echilibrul dintre viața personală şi cea profesională $(r=-.31, p<.001)$, siguranța postului de muncă $(r=-.23, p<.001)$, control $(r=-.18, p<.05)$, şi diverse aspecte ale muncii $(r=-.22, \quad p<.001) \quad$ Pentru scalele Supraîncărcarea muncii, Resurse şi comunicare, Salarizare şi beneficii nu s-au obținut valori semnificative statistic, dar coeficienții de corelație păstrează sensul negativ. $O$ asociere mult mai puternică şi constantă se poate observa între sursele de stres şi percepția angajamentului organizației față de angajat. Toate corelațiile sunt semnificative statistic şi negative, indicând faptul că cu cât creşte nivelul resimțit de stres, cu atât se reduce nivelul perceput de loialitate din partea organizației.

Intentia de schimbare a locului de muncă corelează semnificativ cu atât cu angajamentul față de organizație ( $r=-.348$, $\mathrm{p}<.001$ ), cât şi cu angajamentul perceput al organizației față de angajat $(r=-.545, p<.001)$. Toți factorii de stres măsurați corelează semnificativ statistic cu angajamentul perceput al organizației față de angajați; cele mai puternice asocieri se observă în cazul variabilelor Relații profesionale ( $r=-.335$, $p<.001)$ şi Control $(r=-.309, p<.001)$.
Valoarea foarte ridicată şi semnificativă statistic a coeficientului de corelație obținut între angajamentul perceput al organizației față de membrii organizației şi angajamentul membrilor față de companie $(r=.742, p<.001)$ sugerează că măsura în care angajații percep că organizația este interesată de ei, urmăreşte binele lor, este asociată cu un răspuns similar din partea lor: creşterea nivelului de dedicare față de organizație.

Ca şi în alte investigații ale stresului în contextul fuziunilor şi achizițiilor, diferențele demografice dintre angajații afectați nu influențează percepția acestor schimbări. Singura diferență semnificativă apare în dreptul siguranței postului de muncă $(r=-.23$, $\mathrm{p}<.001$ ), indicând faptul că pentru persoanele de sex masculin insecuritatea muncii reprezintă un factor mai puternic de stres, decât pentru cele de gen feminin. Cu privire la angajamentul față de organizație, se pare că acesta creşte uşor odată cu înaintarea în vârstă $(r=.21, p<.05)$. Nu s-au observat relații semnificative statistic între variabilele demografice şi angajamentul perceput al organizației față de angajat. Atât starea de sănătate fizică $(r=.34, p<.001)$, cât şi starea de sănătate psihologică $(r=.24, p<.001)$ prezintă probleme mai degrabă în rândul femeilor, decât a bărbaților, indiferent de vârstă.

\section{Testarea efectului moderator al angajamentului față de organizație}

Pentru a testa ipoteza efectului moderator al angajamentului față de organizație în cadrul relație dintre stresori şi sănătatea fizică şi psihică a angajaților, am urmat paşii recomandați de Baron \& Kenny (1986). Efectul de moderare a fost verificat prin intermediul regresiei ierarhice, pentru două variabile dependente distincte: sănătatea fizică şi sănătatea psihologică. În fiecare caz, în primul pas al regresiei am inclus rezultatul global obținut la scalele de stres (obținut prin calcularea mediei aritmetice a rezultatelor obținute la cele opt scale individuale din secțiunea Percepții asupra muncii), în al doilea pas, pe lângă stres s-a adăugat angajamentul față de organizație, iar în al treilea, alături de primele două variabile independente, am introdus şi interacțiunea dintre stres şi angajament. Pentru obținerea variabilei de interacțiune Stres $x$ Angajament am apelat la metoda centrată, pentru reducerea şanselor de multicolinearitate şi a valorilor erorilor standard mai ridicate (Sava, 2004). Nu am considerat 
necesar controlul variabilele demografice, datorită faptului că nu am obținut corelații semnificative între acestea şi sursele de stres, respectiv consecințele stresului măsurate prin chestionar. Din punct de vedere tehnic condițiile necesare pentru aplicarea regresiei au fost îndeplinite. Rezultatele obținute în urma analizelor de regresie realizate sunt prezentate în Tabelul 2.

Tabelul 2. Analiza de regresie ierarhică

\begin{tabular}{ccccccccc}
\hline $\begin{array}{c}\text { Variabila } \\
\text { dependentă }\end{array}$ & Pas & Predictori & $\boldsymbol{R}^{2}$ & $\boldsymbol{\Delta R}^{2}$ & $\boldsymbol{d f 1}$ & $\boldsymbol{d f 2}$ & $\begin{array}{c}\boldsymbol{F} \\
\boldsymbol{s c h} .\end{array}$ & $\boldsymbol{p}$ \\
\hline \multirow{2}{*}{$\begin{array}{c}\text { Sănătatea } \\
\text { fizică }\end{array}$} & 1 & Stresul ocupațional & .034 & .027 & 1 & 138 & 4.91 & .05 \\
& 2 & Angajament față de org. & .050 & .036 & 1 & 137 & 2.30 & n.s. \\
\hline \multirow{2}{*}{ Sănătatea } & 1 & Interacțiune (S x AO) & .059 & .038 & 1 & 136 & 1.20 & n.s. \\
psihologică & 2 & Antresul ocupațional & .149 & .143 & 1 & 138 & 24.13 & .001 \\
& 3 & Interacțiune (S x AO) & .174 & .156 & 1 & 136 & .068 & n.s. \\
\hline
\end{tabular}

Rezultatele analizei de regresie arată că în cazul sănătății fizice, stresul ocupațional a fost singurul predictor semnificativ $(\mathrm{F}(1,138)$ $=4.91, p<.05)$. În condițiile păstrării constante $a$ nivelului resimțit de stres, nici angajamentul față de organizație şi nici interacțiunea dintre cele două variabile independente nu aduc explicații suplimentare pentru nivelul de sănătate fizică. Rezultatele nu susțin ipoteza 1a, conform căreia angajamentul față de organizație moderează relația dintre stresori şi nivelul perceput al sănătății fizice. În cazul sănătății psihologice atât stresul ocupațional, cât şi angajamentul față de organizații au contribuții individuale semnificative în explicarea nivelului perceput de sănătate psihologică, dar nu şi în interacțiune. Astfel, stresul ocupațional explică $14,9 \%$ din varianța sănătății psihologice $(F(1,138)=24.13$, $\mathrm{p}<.001$ ), iar angajamentul față de organizație aduce un plus explicativ de $2,5 \%$ în cazul sănătății psihologice $(F(1,137)=4.12, p<.05)$. Pe baza acestor rezultate se poate observa o contribuție mult mai mare a stresorilor, decât a nivelului de angajament, în explicarea varianței sănătății psihologice. Rezultatelor obținute nu sprijină ipoteza 1 , conform căreia angajamentul indivizilor față de organizație moderează impactul surselor de presiune asupra sănătății fizice, psihologice şi intenției de schimbare a locului de muncă. Dimpotrivă, susțin efectul direct al stresului asupra acesteia.

\section{Testarea efectului moderator al angajamentului perceput al organizației față de angajat}

Aceeaşi procedură a fost repetată şi în cazul angajamentului perceput al organizației față de angajat. Astfel, prin intermediul regresiei ierarhice am controlat influența stresului ocupațional şi a angajamentului perceput al organizației față de angajat, pentru a verifica măsura în care există un efect de interacțiune între cele două variabile, care explică nivelul sănătății fizice şi a celei psihologice. Nici în acest caz nu au existat situații speciale din punct de vedere tehnic, condițiile necesare aplicării regresiei fiind susținute. Rezultatele obținute sunt prezentate în Tabelul 3.

Rezultatele din tabelul 3 sprijină ipoteza conform căreia angajamentul perceput al organizației față de angajat moderează relația dintre stresori şi sănătatea fizică $\left(R^{2}=0.122, p<.001\right)$ şi psihologică $\left(R^{2}=0.231\right.$, $\mathrm{p}<.05)$, în condițiile controlării influenței directe a celor doi predictori.

Modelul care ia în calcul interacțiune dintre stresul ocupațional şi angajamentul perceput al organizației față de angajat explică $12,2 \%$ din varianța sănătății fizice a angajaților, contribuind cu un plus de $6 \%$ față de cele $6,2 \%$ explicate de stresul ocupațional şi nivelul perceput al angajamentului organizației față de angajați.

Prin urmare, rezultatele susțin ipoteza 2a, conform căreia angajamentul perceput al organizației față de angajat moderează relația dintre stresori şi nivelul perceput al sănătății fizice. La nivel analitic, din modelul estimativ final se observă că toți trei predictorii incluşi în model, contribuie semnificativ la explicarea sănătății fizice. Coeficienții de regresie indică o relație directă între stresori şi frecvența problemelor de sănătate $(\beta=.262, \quad p<.05)$ şi relații negative între numărul şi frecvența 
simptomelor negative de sănătate şi angajamentul perceput al organizației față de angajat $\quad(\beta=-.203, \quad p<.05) \quad$ şi variabila interacțiune $(\beta=-.290, p<.05)$.

Tabelul 3. Analiza de regresie ierarhică

\begin{tabular}{|c|c|c|c|c|c|c|c|c|}
\hline $\begin{array}{c}\text { Variabila } \\
\text { dependentă }\end{array}$ & Pas & Predictori & $R^{2}$ & $\Delta R^{2}$ & $d f 1$ & $d f 2$ & $\begin{array}{c}F \\
\text { sch. }\end{array}$ & $p$ \\
\hline \multirow{3}{*}{$\begin{array}{l}\text { Sănătatea } \\
\text { fizică }\end{array}$} & 1 & Stresul ocupațional & .034 & .027 & 1 & 138 & 4.91 & .05 \\
\hline & 2 & Angajament perceput al org. & .062 & .048 & 1 & 137 & 4.05 & .05 \\
\hline & 3 & Interacțiune (S x APO) & .122 & .103 & 1 & 136 & 9.26 & .001 \\
\hline \multirow{3}{*}{$\begin{array}{c}\text { Sănătatea } \\
\text { psihologică }\end{array}$} & 1 & Stresul ocupațional & .149 & .143 & 1 & 138 & 24.13 & .001 \\
\hline & 2 & Angajament perceput al org. & .209 & .198 & 1 & 137 & 10.46 & .001 \\
\hline & 3 & Interacțiune (S x APO) & .231 & .214 & 1 & 136 & 3.79 & .05 \\
\hline
\end{tabular}

Interacțiune dintre stresul ocupațional şi angajamentul perceput al organizației față de angajat explică 23,1\% din varianța sănătății psihologice, față de $20,9 \%$ cât explică împreună cei doi predictori controlați, diferența dintre cele două modele fiind semnificativă statistic $(F(1,136)=3.79, p<.05)$. Rezultatele oferă suport pentru ipoteza $2 \mathrm{~b}$, conform căreia angajamentul perceput al organizației față de angajat moderează relația dintre stresori şi sănătatea psihologică a angajaților. Inspecția coeficienților de regresie reflectă 0 relație directă între stresori şi frecvența problemelor de sănătate psihologică raportate de angajați $(\beta=.372, p<.00)$ şi inverse între angajamentul perceput al organizației față de angajat $(\beta=-$ .279, $\mathrm{p}<.001)$ şi al interacțiunii dintre cei doi predictori $\quad(\beta=-.174, \quad p<.05) \quad$ şi variabila dependentă. Tot pe baza coeficienților de regresie putem observa că nivelul de stres resimțit influențează cel mai mult varianța sănătății psihologice.

În concluzie, datele obținute în cadrul acestor modele de regresie sprijină ideea că influența stresorilor organizaționali asupra sănătății fizice şi psihologice a angajaților este moderată de nivelul perceput al angajamentului organizației față de membrii săi. Cu alte cuvinte, în cazul în care angajații percep un nivel ridicat al angajamentului organizației față de ei, efectul stresorilor asupra sănătății personale va fi diminuat.

\section{Discuții şi implicații}

În ansamblu rezultatele studiului reflectă un nivel mediu de stres al angajaților companiei achiziționate, care nu diferă semnificativ de nivelul de stres înregistrat la nivelul populației generale. Există totuşi o serie de informații strânse prin intermediul chestionarului suplimentar de date demografice şi biografice, care ne determină să fim sceptici cu privire la acceptarea acestor rezultate ca fiind în totalitate acurate.

Deşi nivelul raportat de stres în urma completării ASSET este la un nivel mediu, din chestionarul biografic reiese faptul că relațiile între colegii de muncă nu sunt foarte strânse: doar $33,1 \%$ obişnuiesc să se întâlnească cu colegii de muncă şi în afara orelor de program, în timp ce 66,2\% nu au alte relații decât strict profesionale cu colegii lor de muncă şi nu se întâlnesc în afara contextului formal al muncii. Echilibru viața profesională - viața personală, deşi evaluat ca un factor de stres de nivel mediu, are un impact semnificativ asupra sănătății psihologice precare $(r=, 295, p<.001)$, care este un indicator al unei presiuni excesive la locul de muncă şi al resimțirii stresului. În plus, orele de muncă lucrate depăşesc în cele mai multe cazuri (55\%), orele de muncă trecute în contractul de muncă, iar dificultățile în a găsi timp pentru relaxare raportate de $56 \%$ dintre respondenți constituie argumente care susțin prezența unui anumit nivel de interferență între muncă şi responsabilitățile de familie şi o supraîncărcare a muncii, în anumite situații. Inabilitatea de a găsi timp pentru relaxare, socializare sau hobby-uri pot fi un indicator al stresului (Pitariu, Tureanu \& Peleaşă, 2008). În ciuda nivelului mediu obținut la scala de Control, 72\% dintre angajați consideră că deciziile referitoare la obiective şi strategii sunt luate de către conducerea corporației, conducerea locală neavând această putere.

Consecințele stresului ocupațional se manifestă în două direcții majore: asupra sănătății fizice şi psihologice a individului şi 
asupra atitudinilor acestuia față de muncă şi organizație, având consecințe asupra productivității şi performanțelor profesionale obținute.

Nivelul raportat de sănătate fizică şi psihologică se situează la nivel mediu. Autorii testului recomandă însă interpretarea unui nivel mediu în termenii sănătății precare, datorită formulării negative a itemilor. Dintre persoanele incluse în acest studiu, $12 \%$ au avut o boală importantă în ultimele 6 luni, $22,5 \%$ au absentat de la muncă din motive de sănătate în ultimele două luni şi $55,8 \%$ au fost cel puțin o dată la medic, în ultimele trei luni. În concordanță cu datele din literatura de specialitate (Cartwright \& Hudson, 2000) stresul în cazul achizițiilor are o influență mult mai marcantă asupra sănătății psihologice, decât asupra sănătății fizice. Datele de cercetare susțin că problemele psihice asociate stresului provocat de achiziții poate dura până la patru ani de la tranziția organizațională (Cooper \& Payne, 1988, în Cartwright \& Cooper, 2000). Deşi toate sursele de stres investigate au fost asociate semnificativ statistic cu nivelul sănătății psihologice, cel mai ridicat grad de covarianță a fost observat în cazul variabilei Supraîncărcarea muncii. Acest rezultat poate fi explicat pe de-o parte prin reducerile de personal prin care a trecut organizația, ceea ce a determinat automat creşterea numărului de sarcini şi responsabilități pentru cei care au rămas în organizație. Pe de altă parte, noua conducere a implementat sisteme de lucru şi proceduri noi, iar angajații au fost puşi în situația de a învăța o serie de cunoştințe şi deprinderi noi, fapt care a fost interpretat ca şi o supraîncărcare.

Atât nivelul angajamentului perceput al organizației față de membrii săi, cât şi nivelul angajamentului angajaților față de organizație sunt scăzute. Rezultatele obținute la aceste scale demonstrează reflectă faptul că angajații consideră că nu sunt suficient respectați de către organizația din care fac parte, nu simt că merită să depună acele eforturi suplimentare pentru organizație şi nu simt că organizația este preocupată de ei. Percepția neloialității organizației determină reducerea angajamentului personal față de organizație.

Rezultatele obținute în cadrul acestui studiu eşuează în demonstrarea unui efect moderator al angajamentului față de organizație în relația dintre stresori şi consecințele acestora asupra sănătății fizice, psihologice şi a intenției de schimbare a locului de muncă. Prin urmare ipoteza cu privire la rolul de tampon al angajamentului față de organizație în situații de turbulență organizațională nu a fost susținută empiric în acest caz. Una dintre explicații ar putea fi pusă pe seama faptului că schimbările majore şi intense în cadrul organizației studiate au avut loc cu doi ani în urmă, în momentul realizării evaluării angajații confruntându-se cu schimbări de amplitutine mai mică, în comparație cu cele care au urmat imediat după anunțarea oficială a achiziției. Prin urmare, în cazul de față stresul este unul cronic, de durată şi nu unul intens şi acut. Asocierile semnificative statistic obținute între factorii de stres şi sănătatea fizică şi psihologică, dar şi între stres şi angajamentul față de organizație şi intenția de schimbare a locului de muncă sunt în acord cu alte concluzii ale cercetărilor publicate în domeniu (Buono \& Bowditch, 2003; Cartwright \& Cooper, 1993; Cartwright \& Hudson, 2000; Fairfield - Sonn, et al., 2002; Ivancevich, Schweiger \& Power, 1987)

Deşi nu a putut fi demonstrat un efect de moderare al angajamentului față de organizație, rezultatele analizelor de regresie demonstrează clar faptul că această variabilă constituie un predictor important al intenției de schimbare a locului de muncă şi al sănătății psihologice, dar nu şi al sănătății fizice. Rezultate similare au fost obținute şi de Begley \& Czajka (1993): în studiul realizat de ei, nu au identificat corelații semnificative între angajamentul față de organizație şi acuzele somatice ale participanților la cercetare. Într-o cercetare realizată pe un lot de avocați, Kobasa (1982) a identificat o relație semnificativă între angajament şi consecințele stresului, dar nu şi între angajament şi boală. Prin urmare, în situația unui stres cronic, relația dintre angajamentul față de organizație şi consecințele stresului pare să fie una directă şi nu de moderare.

Al doilea potențial moderator urmărit de acest studiu a fost acela al angajamentului perceput al organizației față de angajat. Rezultatele obținute în urma analizelor de regresie sprijină ipoteza referitoare la rolul de moderator al angajamentului perceput al organizației față de angajat, în relația stresori sănătate fizică şi psihologică.

Demonstrarea efectului moderator al percepției angajamentului organizației față de angajat constituie un element important de luat în considerare în planificarea şi dezvoltarea strategiilor de implementare a achizițiilor. 
Gestionarea acestui proces într-o manieră care să comunice angajaților respect şi apreciere din partea organizației, poate contribui la reducerea consecințele negative ale stresului asupra indivizilor, şi implicit şi asupra organizației. Loialitatea organizației față de membrii săi reprezintă un aspect extrem de sensibil şi vulnerabil în condițiile unei achiziții. Schimbările inerente fuziunilor şi achizițiilor influențează în mod direct practicile şi politicile de distribuire a posturilor şi a recompenselor în organizații (Napier, 1989). Modalitatea de luare a deciziilor de distribuire a resurselor organizaționale constituie 0 oportunitate de învățare şi în acelaşi timp o acțiune simbolică, ce transmite angajaților faptul că în calitate de membrii ai organizației vor fi (sau nu) tratați corect şi cu respect. Rezultatele obținute în cadrul acestei cercetări subliniază încă odată importanța acordării atenției factorilor umani implicați în fuziuni şi achiziții. Totodată, considerăm că rezultatele sunt optimiste, în sensul că aduc un argument în favoarea faptului că achizițiile nu trebuie neapărat să aibă consecințe distructive asupra sănătății angajaților şi a productivității organizaționale, sugerând o modalitate prin care pot fi contracarate sau cel puțin limitate efectele negative ale stresului asociat perioadei de integrare.

\section{Concluzii}

Studiul de față şi-a propus investigarea principalelor surse de presiune resimțite de angajați în contextul unei achiziții internaționale, precum şi testarea efectului de moderare al angajamentului față de organizație, respectiv a angajamentului perceput al organizației față de angajat, în relația dintre sursele de stres şi consecințele acestuia asupra sănătății fizice şi psihologice a indivizilor implicați.

Rezultatele obținute au pus în evidență experimentarea unui nivel mediu al stresului, rezultatele obținute nefiind semnificativ diferite de cele obținute pe populația generală, un nivel mediu al sănătății fizice şi psihologice şi un nivel scăzut al angajamentului față de organizație, dar şi al angajamentului perceput al organizației față de angajat.

Dintre cele două efecte de moderare testate, doar unul a obținut suport statistic. Rezultatele analizelor de regresie ierarhică nu au sprijinit ipoteza formulată cu privire la rolul de moderator al angajamentului față de organizație, susținând un efect direct angajamentului asupra sănătății psihologice şi a intenției de schimbare a locului de muncă, dar nu şi asupra sănătății fizice. Ipoteza referitoare la rolul de moderator al angajamentului perceput al organizației față de angajat a fost susținută de rezultatele obținute, sugerând faptul că impactul diferitelor surse de presiune din organizație asupra sănătății fizice şi psihologice a angajaților este atenuat în cazul celor care percep un nivel ridicat de loialitate şi dedicare din partea organizației.

Chiar dacă la un nivel mai redus, în comparație $\mathrm{cu}$ alte rezultate publicate în literatura de specialitate, cercetarea de față susține că fuziunile şi achizițiile sunt evenimente disruptive pentru viața angajaților implicați şi duc la creşterea nivelului de stres şi incertitudine asociate la rândul lor cu o serie de consecințe disfuncționale (atitudini negative față de muncă şi organizație, nivel deficitar al sănătății personale), în cazul în care schimbările nu sunt implementate cu atenție şi considerație față de resursele umane din cadrul organizațiilor partenere. În contextul creşterii frecvenței cu care organizațiile se implică în acest tip de tranzacții şi în România, considerăm esențială dezvoltarea acestei linii de cercetare şi identificarea acelor patternuri specifice contextului social, cultural şi economic (Pitariu, 2006).

\section{Rezumat}

Fuziunile şi achizițiile sunt evenimente corporaționale care au potențialul de a crea un nivel ridicat de stres, cu consecințe la nivel psihologic, comportamental şi fizic, ridicând probleme serioase atât asupra funcționării indivizilor, cât şi a companiilor în care lucrează aceştia. În contextul intensificării investițiilor străine directe în România sub forma achizițiilor şi a lipsei cercetărilor psihologice în domeniul acestui tip de transformări organizaționale, studiul de față şi-a propus identificarea principalelor surse de stres întâlnite în contextul unei companii româneşti, achiziționate de un investitor străin şi a efectului de moderare al angajamentului organizațional asupra relației dintre stresori şi sănătate. Cercetarea a fost fundamentată pe modelul stresului dezvoltat de Cartwright \& Cooper (2002). Rezultatele obținute au evidențiat un nivel moderat al stresului resimțit, dar şi al sănătății fizice şi psihologice, în schimb au pus în evidență un nivel redus atât al angajamentului față de organizație, cât şi al angajamentului perceput al organizației față de angajați. Nu s-a obținut suport pentru rolul de moderarator al angajamentului față 
de organizație, rezultatele obținute susținând doar un efect direct al acestuia asupra sănătății fizice şi psihologice. Analiza de regresie ierarhică a pus în evidență însă efectul moderator al angajamentului perceput al organizației față de angajat, în relația dintre sursele stresului şi consecințele acestuia asupra sănătății fizice şi psihologice. Considerăm că rezultatele obținute sunt optimiste, sugerând posibilități de management al procesului de integrare într-o manieră care să reducă efectele negative, în general asociate cu aceste schimbări.

Cuvinte cheie: stresul ocupațional, angajament organizațional, moderare, fuziuni şi achiziții

\section{Bibliografie}

Applebaum, S.H., Lefrancois, F., Tonna, R. \& Shapiro, B.T. (2007). Mergers 101 (part two): training managers for culture, stress and change challenges. Industrial and Commercial Training, 39, 4, 191-200.

Ashford, S.J. (1988). Individual strategies for coping with stress during organizational transitions. Journal of Applied Behavioural Science, 24, 1, 19-36.

Baron, R.M. \& Kenny, D.A. (1986). The moderatormediator variable distinction in social psychological research: conceptual, strategic and statistical considerations. Journal of Personality and Social Psychology, 51, 6, 1173-1182.

Beehr, T.A. \& Newman, J.E. (1978). Job stress, employee health and organizational effectiveness: A fact analysis, model and literature review. Personnel Psychology, 3, 477-497.

Begley, T.M. \& Czajka, J.M. (1993). Panel analysis of the moderating effects of commitment on job satisfaction, intent to quit and health following organizational change. Journal of Applied Psychology, 78, 4, 552-556.

Bruckman, J.C. \& Peters, S.C. (1987). Mergers and acquisitions: The human equation. Employment Relations Today, 14, 55-63.

Buono, A. F. \& Bowditch, J.L. (2003). The human side of mergers and acquisitions. San Francisco: Jossey-Bass.

Cartwright, S. \& Cooper, C.L. (1990). The impact of mergers and acquisitions on people at work: existing research and issues. British Journal of Management, 1, 65-76.

Cartwright, C. \& Cooper, C.L. (1993a). The psychological impact of merger and acquisition on the individual: A study of building society managers. Human Relations, 46,3, 327-347.

Cartwright, C. \& Cooper, C.L. (1993b). The role of culture compatibility in successful organizational marriage. Academy of Management Executive, 7,2, 57-70.

Cartwright, S. \& Cooper, C.L. (1994). The human effects of mergers and acquisitions. Journal of Organizational Behavior, 1, 47-61.

Cartwright, C. \& Cooper, C.L. (1995). Organizational marriage: "hard" versus „soft" issues? Personnel Review, 24, 3, 32-42.

Cartwright, S. \& Cooper, C.L. (1996). Managing Mergers Acquisitions \& Strategic Alliances. Integrating People and Cultures. Oxford: Butterworth-Heinmann.

Cartwright, S. \& Hudson, S.L. (2000). Coping with mergers and acquisitions. In R.J. Burke \& C.L. Cooper (Eds.). The organization in crisis. Downsizing, restructuring and privatization. Oxford: Blackwell Publishing.

Cartwright, S. \& Schoenberg, R. (2006). Thirty years of mergers and acquisitions research: Recent advances and future opportunities. British Journal of Management, 17, S1-S5.

Cooper, C.L. \& Bramwell, R. (1992). A comparative analysis of occupational stress in managerial and shopfloor workers in the brewing industry. Work and Stress, 6, 172-138.

Cooper, C.L. \& Cartwright, S. (1994). Healthy mind; healthy organization - A proactive approach to occupational stress. Human Relations, 47, 455-471.

Cunha, R.C.E. \& Cooper, C.L. (1998). Privatisation and the human factor. Journal of Applied Management Studies, 7, 2, 201-210.

Davy, J.A., Kinicki, A., Kilroy, J \& Scheck, C. (1988). After the merger: dealing with people's uncertainty. Training and Development Journal, November, 57-61.

Dearborn, M.J. \& Hastings,J.E. (1987). Type A personality as a mediator of stress and strain in employed women. Behavioural medicine, $13,50-60$.

Elsass, P.M. \& Veiga, J.F. (1994). Acculturation in acquired organizations: A force-field perspective. Human Relations, 47,4, 431453.

Fairfield-Sonn, J.W., Ogilvie, J.R. \& DelVecchio, G.A. (2002). Mergers, acquisitions and longterm employee atittudes. Journal of Business and Economic Studies, 8, 2, 1-16.

Faragher, E.B., Cooper, C.L. \& Cartwright, S. (2004). A shortened stress evaluation tool (ASSET). Stress and Health, 20, 189-201.

Folkman, S., Lazarus, R.S., Dunkel-Schetter, C., DeLongis, A., Gruen, R.J. (1986). Dynamics of a Stressful Encounter: Cognitive Appraisal, Coping and Encounter Outcomes. Journal of Personality and Social Psychology, 50, 5, 992-1003.

Hambrick, D.C. \& Canella, A.A. (1993). Relative standing: A framework for understanding departures of acquired executives. Academy of Management Journal, 36, 733-762. 
Howard, J.D., Cunningham, D.A. \& Rechnitzer, P.A. (1986). Role ambiguity, type A behaviour and job satisfaction: moderating effects on cardiovascular and biochemical responses associated with coronary risk. Journal of Applied Psychology, 71, 95-101.

Irving, P.G. \& Coleman, D.F. (2003). The moderating effect of different forms of commitment on role ambiguity - job tension relations. Canadian Journal of Administrative Sciences, 20, 2, 97-106.

Ivancevich, J.M., Schweiger, D.M. \& Power, F.R. (1987). Strategies for managing human resources during mergers and acquisitions. Human Resource Planning, 10, 1, 19-35.

Kaufman, G.M. \& Beehr, T.A. (1989). Occupational stressors, individual strains and social support among police officers. Human Relations, 42, 185-197.

Kobasa, S.C. (1982). Commitment and coping in stress resistance among lawyers. Journal of Personality and Social Psychology, 42, 4, 707-717.

Larsson, R. \& Lubatkin, M. (2001). Achieving acculturation in mergers and acquisitions: An international case survey. Human Relations, 54, 12, 1673-1607.

Lazarus, R.S., DeLongis, A., Folkman, S., Gruen, R. (1985). Stress and Adaptational Outcomes. The Problem of Confounded Measures. American Psychologist, 40, 7, 770-779.

Leong, C.S., Furnham, A. \& Cooper, C.L. (1996). The moderating effect of organizational commitment on the occupational stress outcome relationship. Human Relations, 49, $10,1345-1363$

Levinson, H. (1970). A psychologist diagnoses merger failure. Harvard Business Review, 84-101.

Marks, M.L. (1988). The merger syndrome: The human side of corporate combinations. Journal of Buy Outs and Acquisitions, January/February, 18023.

Marks, M.L. \& Mirvis, P.H. (1992). Rebuilding after the merger: Dealing with survivor sickness. Organizational Dynamics, 21,2, 18-35.

Marks, M.L. \& Mirvis, P.H. (2001). Making mergers and acquisitions work: strategic and psychological preparation. Academy of Management Executive, 15, 2, 80-92.

Mathieu, J.E. \& Zajac, D.M.A. (1990). A review and meta-analysis of the antecedents, correlates and consequences of organizational commitment. Psychological Bulletin, 108, 171-194.

Napier, N.K. (1989). Mergers and acquisitions, human resource issues and outcomes: A review and suggested typology. Journal of Management Studies, 26, 3, 271-289.

Newman, J.M. \& Krzystofiak, F.J. (1993). Changes in employee attitude after an acquisition.
Group \& Organization Management, 18, 4, 390-410.

Panchal, S. \& Cartwright, S. (2001). Group differences in post-merger stress. Journal of Managerial Psychology, 16, 5/6, 424-433.

Pitariu, H. (2006). Stresul profesional la manageri: corelate ale personalității în contextul situației de tranziție social-economică din România. În I. Berar (Ed.) Alexandru Roşca. Omul, savantul, creatorul de şcoală. Bucureşti: Editura Academiei Române.

Pitariu, H.D., Tureanu, V. \& Peleaşă, C. (2008). ASSET. A Shortened Stress Evaluation Tool. An organizational screening tool. Adaptat în România de. Cluj Napoca: Sinapsis.

PriceWaterhouse Cooper, Raport de țară. Accesat la adresa http://www.pwc.com/ro/eng/inssol/surveyrep/MASurveys/MARomaniareport2006ROM .pdf, în 10.07.2008.

Reilly, N.P. (1994). Exploring a paradox: Commitment as a moderator of the stressorburnout relationship. Journal of Applied Social Psychology, 24, 397-414.

Sava, F. (2004). Analiza datelor în cercetarea psihologică. Metode statistice complementare. Cluj Napoca: ASCR.

Schweiger, D.L. \& DeNisi, A.S. (1991). Communication with employees following a merger: a longitudinal field experiment. Academy of Management Journal, 34, 110135.

Schweiger, D.M. \& Ivancevich, J.M. (1985). Human resources: the forgotten factor in mergers and acquisitions. Personnel Administrator, November, 44.

Schweiger, J.M., Ivancevich, D.M. \& Power, F.R. (1987). Strategies for managing human resources during mergers and acquisitions. Human Resource Planning, 10, 1, 19-35.

Sinetar, F.W. (1981). Mergers, morale and productivity. Personnel Journal, November, 863-867.

Somers, M. (1995). Organizational commitment, turnover and absenteism: An examination of direction and interaction effects. Journal of Organizational Behaviour, 16, 49-58.

Terry, D.J., Callan, V.J. \& Sartori, G. (1996). Employee adjustment to an organizational merger: stress, coping and integroup differences. Stress Medicine, 12, 2, 105-122. 